\title{
DE ONTWIKKELING VAN HET ACCOUNTANTSBEROEP IN ISRAEL
}

\author{
door K. D. Hartog
}

Sinds het tot stand komen van de staat Israel is er in accountants kringen hier een duidelijk streven merkbaar om tot een hechtere fundering van het beroep te geraken, en te dien einde ook aanraking met accountants-groeperingen in andere landen te zoeken. Daarom moge ook de aandacht van de Nederlandse accountant op zijn Israelische collega gevestigd worden.

Ten tijde van het Engelse mandaatsbewind was de regeling van het accountantsberoep hier op Engelse leest geschoeid. Een rechtstreekse regeling van het beroep bestond niet, doch de Palestijnse Companies Act schreef voor, overeenkomstig de voorschriften in de Engelse Companies Act, dat iedere N.V. een auditor moest benoemen, die boekhoudingen moest controleren en een balansverklaring moest afgeven. Het recht om deze balansverklaringen af te geven werd beperkt tot die accountants die een licentie daartoe verkregen van de Registrar of Companies. In het begin werden deze licenties uitsluitend verleend aan accountants die lid waren van een der Engelse erkende accountantsverenigingen, doch met de toenemende immigratie bleek deze beperkte regeling onhoudbaar. Er werd toen een speciaal License Committee benoemd, wier taak het was om van hen die een accountants-licentie aanvroegen, de diploma's te onderzoeken. Evenwel werd bepaald dat van 8 met name genoemde Engelse accountantsverenigingen de leden automatisch de bevoegdheid bezaten om in Palestina het accountantsberoep uit te oefenen.

Volgens de hier geschetste regeling werden in de 30 jaren van het Engelse bewind in Palestina, in totaal 84 accountantslicenties afgegeven; hiervan 68 aan Joden, 5 aan Arabieren, 10 aan Engelsen en 1 aan een Duitser. Vermelding verdient nog het feit dat van de aan Joden afgegeven licenties er 4 werden afgegeven op grond van het lidmaatschap van het NIVA.

Indien al de bovengenoemde regeling een zekere handhaving waarborgde van het peil der accountancy in Palestina, dan was er toch wel het nadeel aan verbonden dat $z i j$ een zelfstandige ontwikkeling van het beroep belemmerde: alles werd in Engelse banen geleid. Zo werd door een der Engelse accountantsverenigingen (the Association of Certified and Corporate Accountants) jaarlijks gelegenheid gegeven om hier te lande aan haar examens deel te nemen, doch dit waren Engelse examens, waar het Engelse burgelijk-, handels- en belastingrecht werd geëxamineerd in plaats van het Palestijnse. En er waren een aantal belangrijke verschillen tussen het Engelse en het Palestijnse recht in verschillende wetten.

Met deze en soortgelijke problemen hield zich sinds haar oprichting in 1931 de Association of Public Accountants and Auditors in Palestina bezig, doch haar pogingen hadden weinig succes. Ondanks haar algemene naam, was de Association in feite een organisatie van alleen de Joodse accountants, en het is nimmer gelukt, niettegenstaande herhaalde pogingen, om ook de Arabische en Engelse collega's tot het lidmaatschap te brengen.

Een aangelegenheid waaraan door de Association met volharding is

m a b blz. 217 
gearbeid, is het verkrijgen van een wettelijke regeling van het accountantsberoep, doch haar voorstellen vonden nimmer bij de Mandaatsregering gehoor, die trouwens ook bij andere gelegenheden van haar onwelwillende houding tegenover de Association blijk gaf. In feite kon de Association tijdens het Mandaatsbewind alleen onder haar leden werkzaam zijn, en op dit gebied heeft zij nuttig werk verricht. $Z_{\text {ij stelde }}$ een reglement van tucht vast voor haar leden, er werd een tarief bepaald voor accountantswerkzaamheden en er werd een collectief arbeidscontract gesloten met de assistenten. Regelmatig werden ook studiedagen belegd waarop vakonderwerpen werden besproken, en ook zagen in de loop der jaren enkele publicaties het licht.

Met de oprichting van de Israelische staat is ook voor de Association een nieuw tijdperk ingeluid, en men moet vaststellen dat zij dit heeft begrepen. Reeds in Augustus 1948 wendde het bestuur zich tot de Israelische regering met een uitvoerig memorandum waarin dan onder meer wederom de wettelijke regeling van het beroep an de orde werd gesteld. Tot op heden is deze regeling nog niet tot stand gekomen. maar nu is de oorzaak niet een onwelwillend gehoor. Integendeel: de regering heeft de zaak in overweging genomen, doch meent haar afhanklijk te moeten stellen van een herziening van de Companies Act, waaraan gewerkt wordt. Een vertegenwoordiger der accountants neemt aan de voorbereidende werkzaamheden ter herziening der Companies Act deel, en zo is dus zeker dat op dit belangrijke punt de mening der accountants wordt vernomen. Men kan zeggen dat er een sterke stroming onder accountants bestaat die bij een nieuwe regeling de voorkeur geeft aan een oriëntatie op de Amerikaanse opvattingen (b.v. omtrent de accountantsverklaring), boven het vasthouden aan de Engelse opvattingen op dit punt.

In een andere aangelegenheid heeft de Association reeds een belangrijk resultaat geboekt. Eind 1948 benoemde de regering een commissie ter uitreiking van accountantslicenties, onder voorzitterschap van een lid der accountantsvereniging. Deze commissie, in plaats van te gaan op de wegen harer voorgangster en licenties uit te reiken op grond van het lidmaatschap van een buitenlandse accountantsvereniging, besloot tot het instellen van examens. $Z_{i j}$ benoemde daartoe een examencommissie, samengesteld uit deskundigen voor een aantal vakken. Deze examencommissie ving haar arbeid aan in April 1949, en de moeilijkheden die zij te overwinnen had waren niet gering: overeenstemming te verkrijgen over inhoud en vorm der examens, bepaling der eisen voor ieder vak en, last not least, het opstellen van de examenseisen in het Hebreeuws. Men bedenke dat door de ontwikkeling gelijk hier boven geschetst, de bestudering der accountancy hier steeds in het Engels had plaats gevonden, en daardoor waren er geen Hebreeuwse termen ontstaan voor vele vakuitdrukkingen.

De examencommissie was evenwel doordrongen van het grote belang harer taak en zij heeft met doortastendheid gewerkt. Met grote voldoening kon zij na ruim een half jaar een boekje publiceren dat een tot in alle onderdelen uitgewerkt programma bevatte voor Israelische accountantsexamens. Het examen bestaat uit twee delen, waarvan het eerste deel omvat:

boekhouden contrôleleer 
handelsrecht

economie

belastingrecht

handelskennis.

Het tweede deel omvat:

boekhouden

kostprijsberekening

contrôleleer

handelsrecht

economie

belastingrecht

handelskennis

statistiek

coöperatieven.

De indeling van het examen wijkt aanzienlijk af van het in Nederland gevolgde systeem; er is meer overeenkomst met de Engelse accountantsexamens, maar in zijn onderdelen is het nieuwe programma geheel zelfstandig uitgewerkt. Als geheel is het cen verantwoord begin dat zeker bij zal dragen om de accountantsstudie in Israel te verdiepen.

Het spreekt vanzelf dat ook onder de nieuwe regeling, in dit land van immigranten, aan buitenlandse gediplomeerden in vele gevallen vrijstellingen zullen worden verleend. Doch het is te verwachten dat zelfs een volledig gediplomeerd vakgenoot uit het buitenland geen vrijstelling zal kunnen verkrijgen voor die vakken die specifiek zijn voor Israel, namelijk handels- en belastingrecht.

De eerste examens zullen worden afgenomen in de maand Mei 1950 en naar het zich laat aanzien zal een aanzienlijk antal candidaten er aan deelnemen.

Het arbeidsteriein van de accountant in Israel breidt zich sterk uit. Het bedrijfsleven groeit voortdurend en doet in versterkte mate een beroep op de accountant. Nieuwe wetten worden ook aangenomen die de particulier nopen de hulp van de accountant in te roepen (naast inkomstenbelasting, heft de Israelische regering sinds kort ook Successiebelasting en Waardevermeerderingsbelasting bij de verkoop van onroerende goederen). Van haar kant doet de regering ook een beroep op de accountants: nadat besloten was tot de benoeming van een State's Auditor over te gaan (wiens taak te vergelijken is met de taak van de Algemene Rekenkamer in Nederland) werd een accountant tot dit belangrijke ambt beroepen. Ook op enkele andere belangrijke posten werden accountants benoemd.

Dit overzicht moge een indruk geven van de energie en de ambitie warmee de Israelische accountant zijn beroep uitoefent. 